\title{
Auguste Forel on Ants and Neurology
}

\author{
André Parent
}

\begin{abstract}
Auguste Forel was born in 1848 in the French part of Switzerland. He developed a lifelong passion for myrmecology in his childhood, but chose medicine and neuropsychiatry to earn his living. He first undertook a comparative study of the thalamus under Theodor Meynert in Vienna and then, from 1872 to 1879, he worked as Assistant Physician to Bernhard von Gudden in Munich. This led in 1877 to his seminal work on the organization of the tegmental region in which he provides the first description of the zona incerta and the so-called H (Haubenfeld) fields that still bear his name. In 1879, Forel was appointed Professor of Psychiatry in Munich and Director of the Burghölzli cantonal asylum. He became interested in the therapeutic value of hypnotism, while continuing his work on brain anatomy and ants. His neuroanatomical studies with Gudden's method led him to formulate the neuron theory in 1887, four years before Wilhelm von Waldeyer, who received most of the credit for it. Forel then definitively turned his back on neuroscience. After his retirement from the Burghölzli asylum in 1898, and despite a stroke in 1911 that left him hemiplegic, Forel started to write extensively on various social issues, such as alcohol abstinence and sexual problems. Before his death in 1931 at the age of 83, Forel published a remarkable book on the social world of the ants in which he made insightful observations on the neural control of sensory and instinctive behavior common to both humans and insects.
\end{abstract}

RÉSUMÉ: Entre fourmis et neurologie : Auguste Henri Forel (1848-1931). Auguste Henri Forel (1848-1931). Auguste Forel est né dans le Canton de Vaud en Suisse Romande. Il développa très tôt une passion indéfectible pour l'étude des fourmis, mais opta pour la médecine comme moyen de subsistance. Il entreprit d'abord une étude comparative du thalamus sous la direction de Theodor Meynert à Vienne (1871-1872), puis devint l'assistant de Bernhard von Gudden à Munich (1872-1879), où il réalisa une étude magistrale sur la région tegmentaire du tronc cérébral (1877). Ce travail offre une description détaillée du noyau sous-thalamique, de la zona incerta et des soidisant champs « $\mathrm{H} »$ de Forel. En 1879, Forel fut nommé professeur de psychiatrie à Munich et directeur de l'asile cantonal de Burghölzli. Il s'intéressa alors à la valeur thérapeutique de l'hypnotisme, tout en continuant ses travaux sur le cerveau et les fourmis. Ses études neuroanatomiques le conduisirent à formuler la théorie du neurone dès 1887 , soit quatre ans avant Wilhelm von Waldeyer, qui en recevra seul tout le crédit. Après cet événement, Forel tourna progressivement le dos à la neuroanatomie. Il prit sa retraite en 1898 et, malgré un accident vasculaire cérébral qui le laissa hémiplégique en 1911, il amorça une toute nouvelle carrière. Il la consacra principalement à l'étude des fourmis, mais aussi à différentes questions sociales, dont l'abstinence face à l'alcool et les problèmes sexuels. Peu avant son décès, Forel publia un traité remarquable sur la vie sociale des fourmis dans lequel on retrouve des observations perspicaces sur le contrôle neuronal du comportement instinctif commun aux insectes et à l'homme.

Can. J. Neurol. Sci. 2003; 30: 284-291

Auguste Henri Forel (Figure 1) was born on the first of September 1848 in his grandparents' house La Gracieuse located near Morges, Canton de Vaud, in the French part of Switzerland. His mother, Pauline Morin, was a French Huguenot and his father, Victor Forel, a devoted Swiss Calvinist. Raised under the protection of his pious mother, the timid and secluded Auguste developed very early in life an enduring passion for the study of insects, particularly ants. After a rather unimpressive academic start at Morges and later at Lausanne, Forel entered the medical school in Zurich, hence making his first incursion into the German part of Switzerland. In Zurich, Forel was very much impressed by Bernhard Aloys von Gudden (1824-1886), who elegantly combined neuroanatomical studies - for which he was already famous - with clinical duties as a psychiatrist. Forel thus decided to devote himself to neurology and psychiatry. Although highly motivated for medical studies, Forel devoted all of his summer vacations to myrmecology. He published a few papers on the behavior of ants in local journals and became a member of the Swiss Entomological Society.

In 1871, after having completed his medical studies in Zurich,

From the Centre de Recherche Université Laval Robert-Giffard, Beauport, Québec, Canada.

ReCEIVED NOVEMber 12, 2002. ACCEPTED IN FINAL FORM FEBrUARY 24, 2003. Reprint requests to: André Parent, Centre de Recherche Université Laval RobertGiffard, 2160, Chemin de la Canardière, Beauport, Quebec, Canada, G1J 2G3 


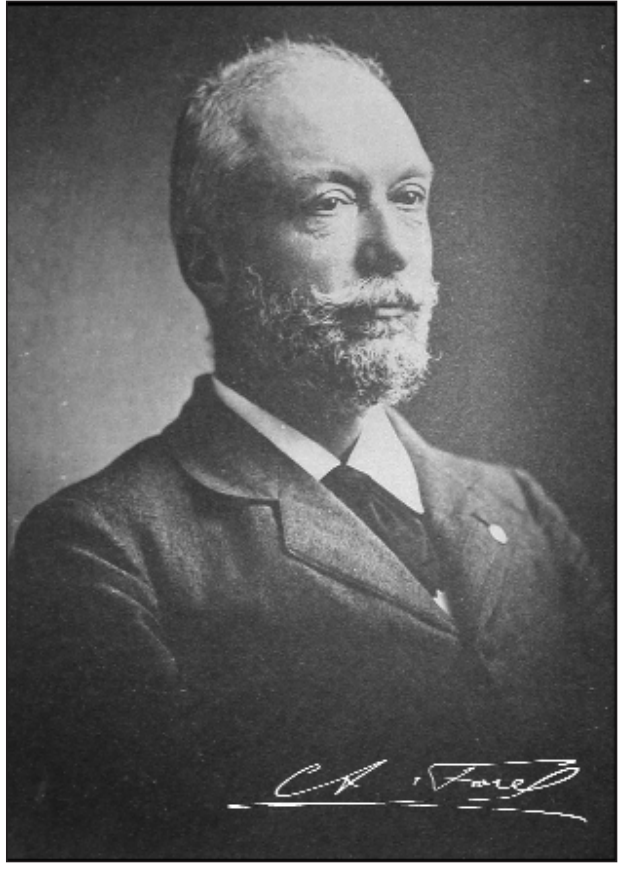

Figure 1: Auguste Forel at age 51. From Clark JG, (ed). Clark University 1889-1899 Decennial Celebration. Worcester: Clark University Press, 1899.

Forel took the cantonal medical examination in Lausanne at the age of 21. Unfortunately, largely because of local medical politics, he failed this exam and spent the rest of the year collecting insects throughout Switzerland and working on a huge monograph devoted to the ants of his country. Forel then left for Vienna where he stayed for seven months (1871-1872) studying neuroanatomy under Theodor Meynert (1833-1892). Meynert was then director of the old insane asylum on Lazarettgasse, as well as a major figure in the field of neuroanatomy and neuropsychiatry. ${ }^{1}$ However, Forel was greatly disappointed by Meynert's lectures and laboratory facilities, as well as by the way the clinical work was organized at the asylum. He thus decided to isolate himself in Meynert's laboratory and undertook a series of studies on the comparative anatomy of the thalamus. Although Forel's results were somewhat at odds with some of Meynert's views about the organization of the thalamus, the master, after some hesitations, offered Forel the opportunity to publish his results in the Proceedings of the Vienna Academy of Sciences. ${ }^{2}$ With this thesis in hand, Forel passed the cantonal medical examination in Lausanne in December 1872, but was not able to obtain a position in a psychiatric institution of his native Canton. $^{3}$

\section{A MAJOR CONTRIBUtion to NEUROANATOMY}

In 1873, Forel moved to Germany, where he became assistant physician to Gudden at Munich's Kreis-Irrenanstalt. However, instead of being put in charge of a clinical ward, Forel saw himself confined to Gudden's laboratory. There, he started by improving the so-called Gudden's microtome, ${ }^{4}$ with which he was able to obtain entire human brain sections. Having this precious tool at hand, he initiated a series of neuroanatomical

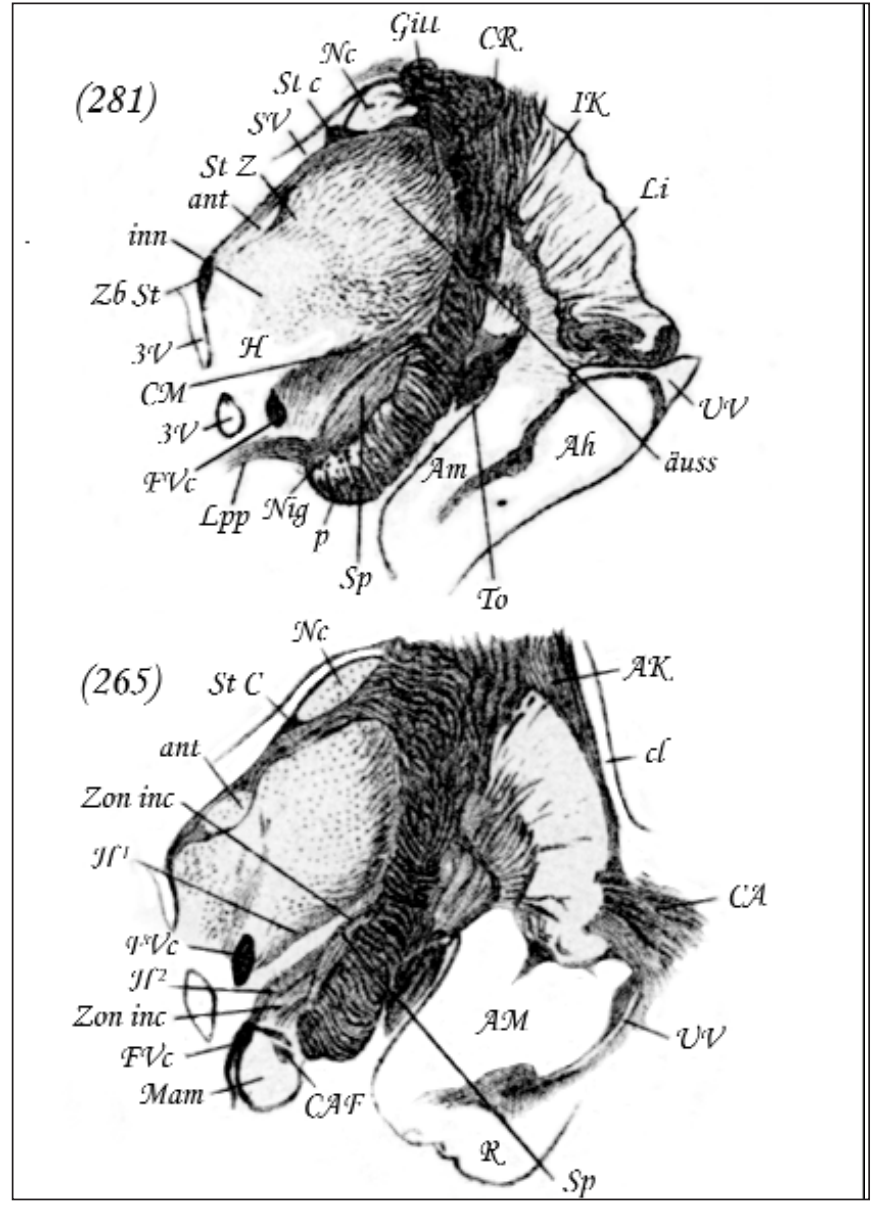

Figure 2: Forel's depiction of the subthalamic and tegmental regions in human. The section shown in the upper panel is slightly more caudal than the one in the lower panel. They correspond respectively to Figure 12 (section \# 281) and Figure 14 (section \# 265) that are part of the fourth plate in Forel's 1877 paper. The field $H(H)$ (Haubenfeld; Feld $H$ or dorsales Mark der Regio subthalamica) is clearly visible in the upper panel, whereas field $\mathrm{Hl}\left(\mathrm{H}^{l}\right.$; Feld $\mathrm{H}^{l}$ or dorsale Abteilung aus dem Feld $\mathrm{H})$, field $\mathrm{H} 2\left(\mathrm{H}^{2} ;\right.$ Feld $\mathrm{H}^{2}$ or ventrale Abteilung aus dem Feld $\left.\mathrm{H}\right)$ and the zonal incerta (Zon inc) are well delineated in the lower panel. From Forel A. Untersuchungen über die Haubenregion. Arch Psychiat Nervenkr 1877; 7: 393-495.

studies on the organization of the tegmental region, including the subthalamic region, in humans. The results of this study were reported in a 102 page-long article entitled: Studies on the tegmental region and its ascending connections in the brain of man and various mammals that appeared in $1877 . .^{5}$

In this remarkable paper, Forel, who was then only 29-yearsold, provided the first clear description of the complex nuclear and fibrillar organization of the tegmental region, many components of which still bear his name (Figure 2). This is the case of the tegmental fields of Forel (campus Foreli), which included fields $\mathrm{H}, \mathrm{H} 1$ and $\mathrm{H} 2$, the " $\mathrm{H}$ " standing for the German word Hauben, which refers to the nightcap aspect of this region. The fields $\mathrm{H}, \mathrm{H} 1$ and $\mathrm{H} 2$ correspond respectively to the prerubral field, the thalamic fasciculus and the lenticular fasciculus. Forel's field $\mathrm{H}$ system consists first of the field $\mathrm{H} 2$ fiber system 
that courses in-between the subthalamic nucleus and the zona incerta - a structure that Forel was the first to define - merges with fibers of the ansa lenticularis within field $\mathrm{H}$ to finally form the field $\mathrm{H} 1$ fiber system that ascends towards the ventral tier nuclei of the thalamus (Figure 2). Today, these fibers are known to convey motor information of pallidal and cerebellar origin to the thalamus and they occupy a central position in our current thinking of the pathophysiology of Parkinson's disease. In fact, most current neurosurgical attempts to alleviate the motor symptoms of Parkinson's disease by lesioning or stimulating at high frequency various components of the subthalamic region, including the field $\mathrm{H}$ system, the zona incerta and the subthalamic nucleus, still rest upon Forel's original account of the organization of this brain region.

Forel's paper on the tegmental region was widely acclaimed by the scientific community. Among those who wrote personally to Forel to congratulate him on this major contribution was the discoverer of the subthalamic nucleus himself, the French neuropsychiatrist Jules Bernard Luys. ${ }^{6}$ Luys was particularly proud to see that his name had been eponymically attached to the subthalamic nucleus by Forel. Indeed, this component of the subthalamic region is termed Luyssche Körper, Corpus luysii or Bandelette accessoire de l'olive supérieure von Luys in Forel's writings. However, Forel was very critical of the latter name (accessory band of the superior olive) given by Luys to the subthalamic nucleus. On pages 470-471 of his 1877 paper, one can read: "This term is improper for at least three reasons. First, the word bandelette commonly refers to a band of white matter, whereas the nucleus in question is clearly a mass of gray matter. Second, what Luys called olive supérieure corresponds to the red nucleus of Burdach and not to the superior olivary nucleus of Schröder van der Kolk. Third, Luys' nucleus has nothing to do with either the red nucleus or the superior olivary nucleus." Forel's paper includes a much more accurate description and illustration of the subthalamic nucleus (see Figure 2) than the one provided originally by Luys. ${ }^{7,8}$ It also contains the first microscopic illustration of a neuron of the subthalamic nucleus (Figure 3A), as well as one of the red nucleus (Figure 3B).

After having completed his 1877 paper, which he used as a thesis for aggregation, that is, the competitive state examination required of those aspiring to a University post, Forel became Privat-docent (lecturer) at the Ludwig-Maximilians-Universität in Munich. He nevertheless continued his myrmecological studies and saw his 450 page-long treatise on the ants of Switzerland, which had been published in Zurich in $1874,{ }^{9}$ honored by the Helvetic Society of Natural Sciences and the Académie des Sciences de Paris. Charles Darwin himself wrote to Forel to congratulate him on this very fine accomplishment. The first sentence of Darwin's letter dated October 15, 1874, is as follows: "I have now read the whole of your admirable book and seldom in my life have I been more interested by any book."10

\section{DIRECTOR OF THE BURGHÖLZLI ASYLUM}

In 1879, Forel was appointed director of the Burghölzli asylum and professor of psychiatry at the University of Zurich. His predecessor at the Burghölzli asylum was the German neurologist Julius Eduard Hitzig (1838-1907), who became famous for his work on the electrical stimulation of the motor cortex undertaken in collaboration with Gustave Theodor Fritsch (1838-1927). ${ }^{11}$ The cantonal asylum was wonderfully located; it overhung the lake of Zurich and was surrounded by beautiful wooded hills (Figure 4, upper panel). It also harbored quiet gardens that Forel liked to share with his colleagues for morning clinical reports (Figure 4, lower panel). While spending a considerable amount of his time reorganizing the asylum by setting new and more stringent rules that were applied to both patients and staff, Forel became progressively captivated by all the problems that surround the clinical treatment of mental illnesses. In 1885, he started exploring the therapeutic value of hypnotism by following closely the precepts of Hippolyte

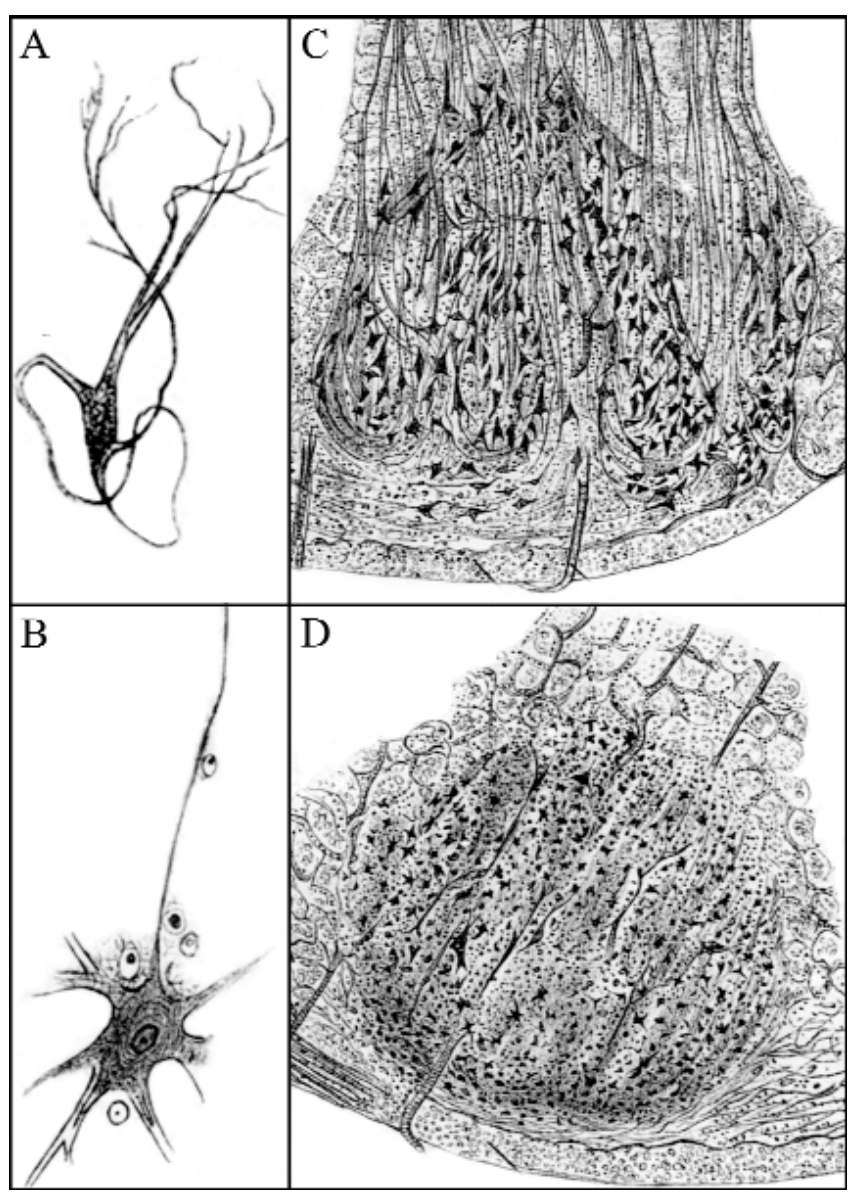

Figure 3: $(\boldsymbol{A}, \boldsymbol{B})$ First illustration ever of a neuron of the subthalamic nucleus (Sp; Luyssher Körper or Corpus Luysii) (A) and of a neuron of the red nucleus (RK; Roten Kern) (B). The subthalamic nucleus neuron was drawn from section \# 504 of a human brain series, whereas the red nucleus neuron comes of a preparation of the brainstem of a dog. From Forel A. Untersuchungen über die Haubenregion. Arch Psychiat Nervenkr 1877; 7: 393-495.

$(\boldsymbol{C}, \boldsymbol{D})$ Drawings showing the facial motor nucleus in a normal guinea pig $(C)$ compared with that of a guinea pig that underwent a section of the facial nerve peripherally $(D)$. The marked loss of cell bodies and related axonal processes caused by the section of the facial nerve is clearly documented in these diagrams. From Forel A. Einige hirnanatomische Betrachtungen und Ergebnisse. Arch Psychiat Nervenkr 1887; 18: 162-198. 


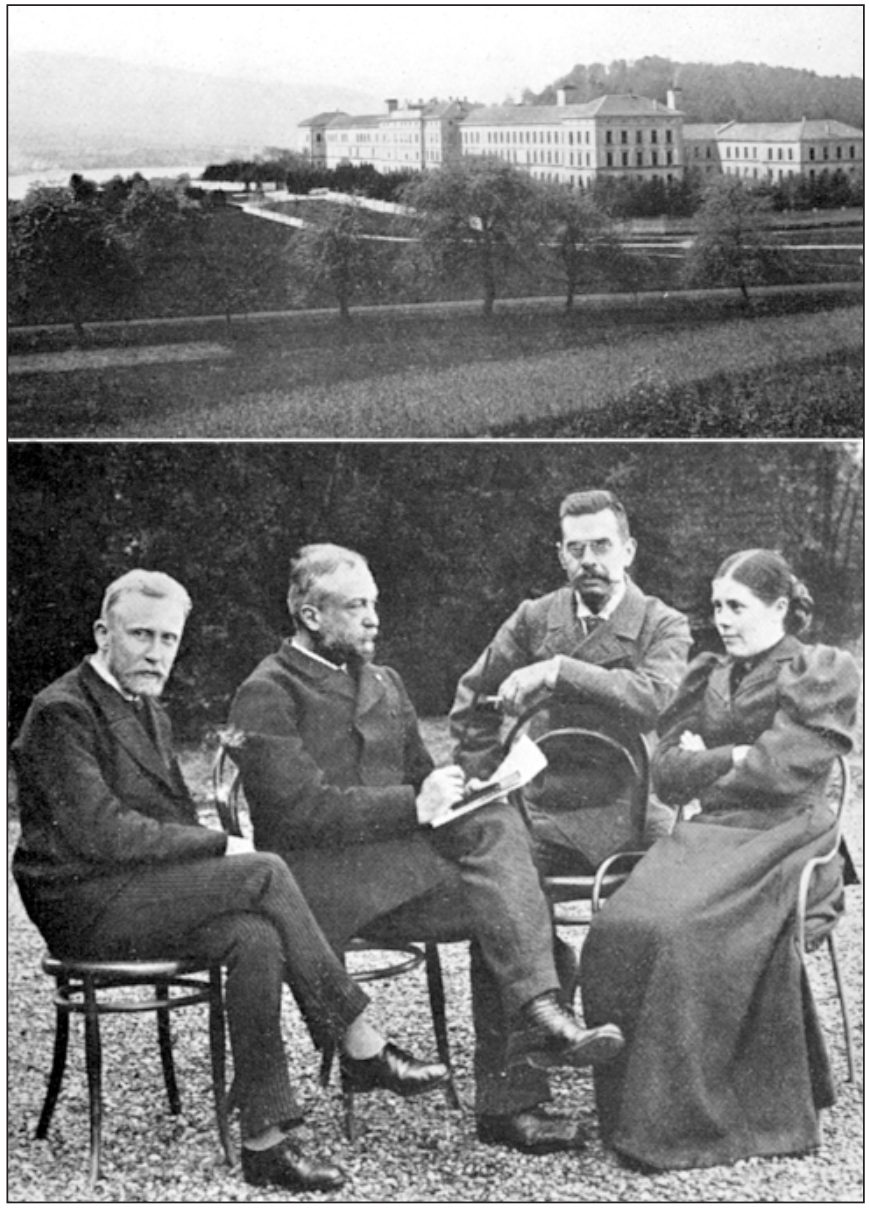

Figure 4: Upper panel: the cantonal asylum at Burghölzli in Forel's day. Lower panel: the morning report at the Burghölzli asylum showing from left to right Dr. Delbrück, Director Forel, Dr. Bach, and Dr. Gottschall. From Forel A. Rückblick auf mein Leben. Zürich: Europa-Verlag, 1935.

Bernheim (1840-1919), head of the so-called École de Nancy that was markedly opposed to Jean-Martin Charcot (1825-1893) and l'École de la Salpêtrière, in regard to mechanisms underlying hysteria and hypnotism. ${ }^{12}$ The famous neuroanatomist Oskar Vogt (1870-1950), who also made ample use of hypnotism in his clinical practice, was a frequent visitor at the Burghölzli asylum. Together, Forel and Vogt founded the Journal für Psychologie und Neurologie in 1892.

\section{THE NEURON DOCTRINE}

Despite a very busy clinical schedule, Forel took the time to set up a research laboratory at the Burghölzli asylum and initiated a series of experimental studies on the origin of some cranial nerves in rodents. By using Gudden's retrograde cell degeneration method, Forel discovered that the section of motor cranial nerves peripherally caused cell degeneration only in small and specific areas of the brainstem (Figure 3C, D). In contrast to what could have been expected if the nervous system was organized as a reticulum - the dominant view at that time this sectioning procedure did not affect adjoining neuronal networks. This finding coupled with observations made on material stained by a method developed earlier by Camillo Golgi (1843-1926), ${ }^{13}$ led Forel to realize that the fibers that he was sectioning belonged to single cells and that both elements formed the fundamental unit of the nervous system. His observations were summarized in a paper entitled: Some considerations and results on brain anatomy that he published in $1887 .{ }^{14}$ On page 166 of this paper, one can read a significant passage: "I believe that all fiber systems or so-called fiber networks in the nervous system are nothing but the processes of single ganglion cells. This process emerges at the bases of the cell. It then emits nervous fibrils that arborize either close to (type II cells) or at long distances from the cell body by forming ramifications that closely intertwine but never really anastomose with one another." Further down (page 171), Forel discusses the organization of the retinal fiber projection in the brain under the followings terms: "Thus, if our assumption is correct, the treelike arborizations of the optic fibers would transmit visual stimuli without direct continuity but solely through intimate contiguity to the cell system of the external geniculate body and, through it, to the visual cortex."

These excerpts, as well as some illustrations that can be found in his 1877 paper (Figure 3), clearly show that Forel understood perfectly well that the so-called Ganglienzelle (nerve cell bodies) and Nervenfortsätze (neuronal processes) were forming single units that he considered the basic elements of the nervous system. ${ }^{15,16}$ They also reveal that Forel had realized that, as is the case at the neuromuscular junction where nerve fibers do not anastomose with muscle fibers, a simple contact between neuronal processes was sufficient to ensure a faithful transmission of the information in the nervous system. This theory became known as the Contact Theory of Forel. ${ }^{17}$

Similar conclusions were reached at about the same time in Leipzig by the famous neuroembryologist Wilhelm His (18311904), who was also of Swiss origin and to whom we own terms as familiar as dendrites, neurite, neuropil, and neuroblasts. By studying the development of the nervous system, His documented the emergence of axonal processes from maturing neuroblasts. He further demonstrated that central processes of sensory cranial nerves do not anastomose with one another as they reach their terminal site in the brain. He reported his findings in a paper that was published at the end $1886,{ }^{18}$ only two months before Forel's paper. Forel was first upset because he had lost priority on this important discovery simply because of the slow publication rate of the Berlin Archiv für Psychiatrie. However, he calmed down when he realized that both sets of data went largely ignored by the scientific community, probably because they represented the first real challenge to the prevailing reticularist view.

His and Forel must be credited for having been the first to demonstrate that the nervous system, as all other living tissues, is composed of distinct cellular and functional units. This theory received a strong impetus from the work of Santiago Ramón y Cajal (1852-1934), who showed convincing images of these neuronal units taken from his material stained by Golgi's method. ${ }^{19}$ Ramón y Cajal's findings received hearty support in Germany, particularly from Rudolph Albert von Kölliker (18171905), who was then the most prominent figure in the field of neuroanatomy. ${ }^{20}$ However, the name that finally became most closely associated with the new theory was that of the imposing 


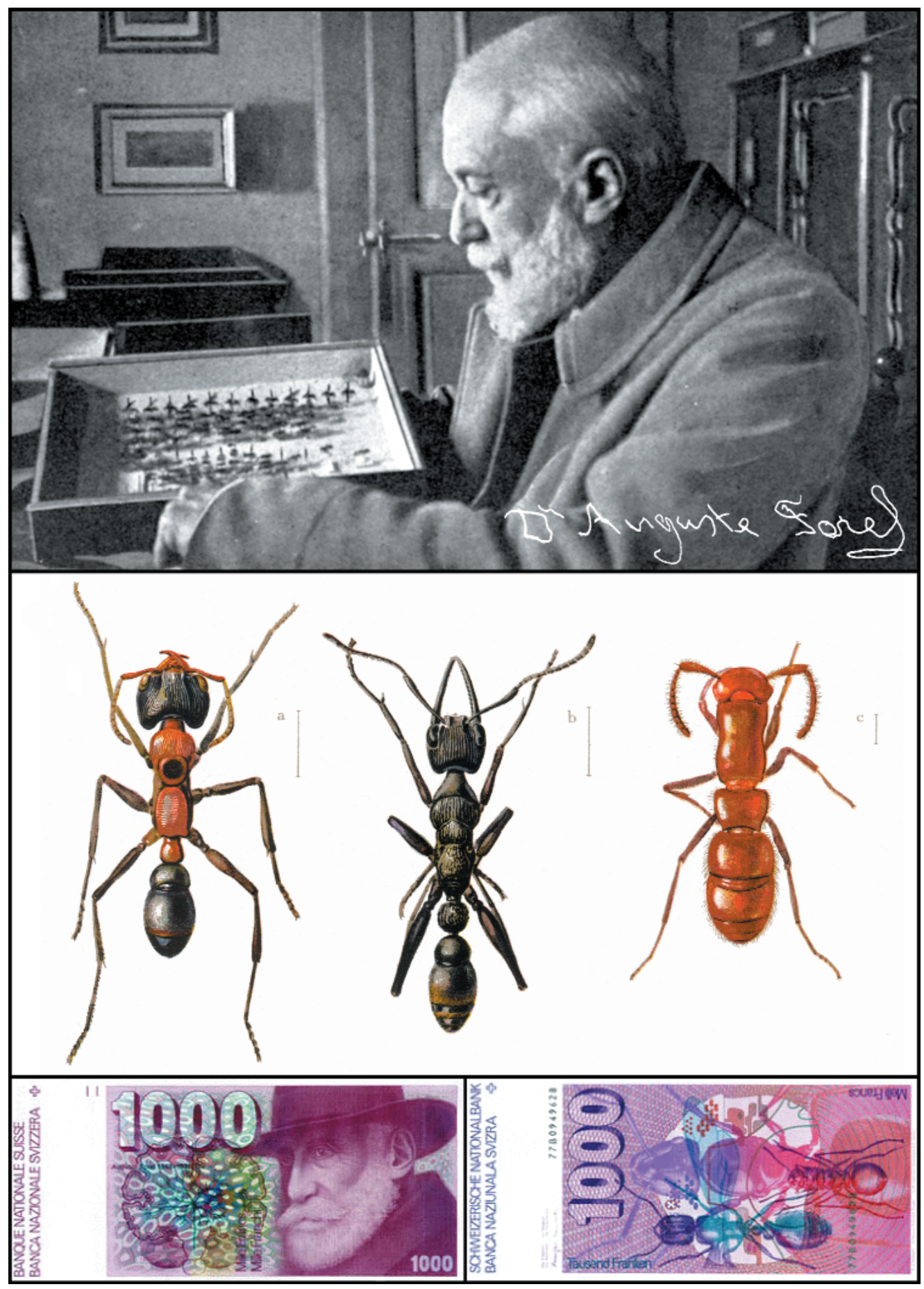

Figure 5: Upper panel: Auguste Forel at Chigny. His unsteady signature betrays the stroke that afflicted him in 1911. Central panel: a reproduction of the first plate of Forel's book on the social world of ants. These beautiful drawings illustrate three different species of ants; they are those of the famous animal painter Erich W. Heinrich, who was hired by Forel to work with him at Yvorne from July to December 1919 on his myrmecological treatise. The work was first published in French (1921-1923), but an English translation by C.K. Ogden appeared as early as 1928. The illustrations in upper and central panels are from the English version of the book: Forel A. The social world of the ants compared with that of man. London and New York: Putnam's Sons. 1928. Lower panel: the twin faces of the 1000-Swiss-franks banknote that was withdrawn from circulation at the end of the 1990s. Forel, at the age of 76, together with a frontal section of the human brain are shown on one face (left), whereas three species of ants superimposed upon a sagittal view of an ant hill appear on the other (right). In 1998, Forel's effigy on this banknote was replaced by that of Jacob Burkardt, a Basle historian of culture. 
director of the Berlin University Anatomical Institute, Wilhelm von Waldeyer (1836-1921). Waldeyer published in 1891 a long and detailed review paper in which the neuron doctrine (Neuronlehre) was formulated the way we know it today and where the term neuron appeared for the first time. ${ }^{21}$ Waldeyer had a keen sense of formulation - we owe him the word chromosome - and a great ability to synthesize various disperse data into a single, coherent theory. ${ }^{15-17}$ Furthermore, he chose the widely read and weekly issued Deutsche medizinische Wochenschrift to publish his paper, which was so influential that it played a major role in the downfall of the reticular theory. Forel reacted with bitterness to the fact that Waldeyer, who did not himself contribute a single observation to support the neuron theory, was about to obtain a worldwide and long-standing recognition for the discovery of the neuron. This event is likely to have contributed to the fact that Forel progressively turned his back on neuroanatomy and neurology.

\section{Retreat at Chigny And Yvorne}

Forel retired from his duties as professor of psychiatry and director of the Burghölzli asylum in 1898 and returned to his native Canton de Vaud, where he settled first at Chigny and later at Yvorne (Figure 5, upper panel). His successor at the head of the Burghölzli asylum was the Swiss psychiatrist Eugen Bleuler (1857-1939), who coined the term schizophrenia and became world-renowned for his clinical work on the Burghölzli schizophrenic patients. ${ }^{22}$

Forel remained very active during more than three decades after his retirement from the Burghölzli asylum. A considerable amount of his time was devoted to myrmecology, but he also started writing extensively on various philosophical and sociological issues, including sexual problems, alcohol abstinence, monism, pacifism and socialism. ${ }^{23,24} \mathrm{He}$ started traveling extensively around the world; collecting ants in Colombia (1896), crusading for alcohol abstinence in Canada (1899) and participating in international meetings on psychological criminology in Russia (1902). After his visit to Toronto in the summer of 1899 , Forel went to Clark University at Worcester, Massachusetts, as an invited guest to the decennial celebration of this Institution, which was very much involved in the research and teaching of psychology. There he gave a lecture on hypnotism and another on the biology of ants, both of which appeared in the jubilee publication of the University that was released later that year. ${ }^{25}$ Ramón y Cajal was one of the other prestigious guests at this event, where he delivered three lectures on different aspects of the neuroanatomical organization of the cerebral cortex. ${ }^{25}$ Although Forel does not allude to the presence of Ramón y Cajal at the Worcester Symposium in his memoirs, ${ }^{3}$ it is worth noting that Ramón y Cajal became interested in myrmecology later in life, as evidenced by the work he published in 1921 on the sensory system of ants. ${ }^{26}$ In May 1911, Forel suffered a cerebral vascular accident that left him hemiplegic and partially aphasic. He then underwent extensive reeducation and learned to write with his left hand at age 64. This allowed him to continue his socio-philosophical writing and entomological work.

In 1920, Forel made his first acquaintance with the supraconfessional world-religion of the Bahá'i, founded in the middle of the 19th century by the Persian Bahá `u lláh. The Bahá'i faith, which advocates the abolition of all sexual, racial, national and religious prejudices and wishes to harmonize the scientific mind with social and cultural concepts, was particularly appealing to Forel. The following excerpt from his testament is particularly revealing: "It is the true religion of the welfare of human society, it has neither priests nor dogmas, and it binds together all the human beings who inhabit this little globe. I have become a Bahá'i. May this religion continue and be crowned with success; this is my most ardent wish". ${ }^{3}$ Forel's faith was rewarded by a "Tablet" that was written for him by Bahá `u lláh himself and which is still considered today by the Bahá'is as one of the most weighty epistle their Master ever wrote. Amazingly, this letter is perhaps the most widespread document related to Forel available today on Internet.

The last major contribution of Forel is an impressive five volume-treatise on the social life of ants that appeared in print between 1921 and 1923. ${ }^{27}$ This monograph is beautifully illustrated (Figure 5, middle panel) and contains insightful observations on the neural control of sensory and instinctive behavior common to humans and insects. It is still considered today a major contribution to the field of myrmecology. Forel died peacefully at La Fourmilière, his home at Yvorne, on July 27,1931 at the age of 83 .

\section{FOREL AND THE SWISS CONTRIBUTION TO NEUROLOGY AND PSYCHOSOCIAL MEDICINE}

Forel left behind him major contributions to several fields of human knowledge. His late interest in the social aspect of various medical problems makes him a worthy descendant of his compatriot Samuel-Auguste Tissot (1728-1797). Tissot was born at Grancy in the Canton de Vaud, very close to Forel's birthplace. He became one of the most famous physicians of the Age of the Enlightenment in Europe because of his seminal contribution to various questions related to public health and preventive medicine. ${ }^{28,29}$ Tissot was a member of several prestigious scientific societies, including the Royal Society of London, and he published an impressive two-volume treatise entitled: The nerves and their diseases in $1800 .{ }^{30}$ In regard to neurology and neuropsychiatry, there is also a certain affiliation between Forel and another Swiss scholar, Johann Caspar Lavater (1741-1801). Lavater was a Protestant pastor who lived in Zurich; he is known to us today chiefly through the highly influential treatise on human physiognomy that he wrote in $1772 .{ }^{31}$ A strong believer of interactions between mind and body, Lavater was looking for traces of the spirit upon bodily features, particularly the head and face (silhouettes). Several years before Franz Joseph Gall (17581828), he formulated the theory that the external surface of the brain is imprinted upon the cranial cavity, which can thus be used to study the organization of the organ of thought.

Forel himself had always been intrigued by the mind and body duality and many of his late writings are nothing but attempts to solve the relationship between brain physiology and brain psychology. ${ }^{32}$ This duality was reconciled in Forel's mind by the concept of monad introduced by Gottfried Wilhelm Leibniz (1646-1716) in reference to what he considered the substantial unit that appears as a force when defined from outside and as a soul or spirit when determined from inside. Forel 
walked even more deeply into scientifically unmapped territories when he wrote his essay on the sexual question. ${ }^{23}$ This book, which provided the first comprehensive treatment of human sexual life from both the biological and the sociological perspective, was immensely popular; it attained enormous sales, was translated into several languages, and went through 17 editions. Forel used this volume to advocate, among other things, the complete legal equality of sexes, formal recognition of woman's housework, legalization of concubinage, free availability of contraceptives, as well as the recognition of homosexuality, which he believed was "quite harmless to the Society." Not surprisingly, such a program proposed by a renowned scientist at the dawn of the 20th century became the target of vehement attacks from members of various religious and conservative circles. ${ }^{33}$

Forel ventured even further on slippery ground when he tackled social hygiene and eugenics issues in his book. He had always been impressed by the American laws allowing forced sterilization, which he thought were applied only in extreme cases. He naïvely considered such laws as eugenic and seriously believed that they might contribute to improve the human race. As an ardent pacifist, Forel deplored the cacogenics of war, that is, the counter-selection which slaughter the best and the healthiest on the battlefield while the old and sick survive at home. Conversely, he believed that he should prevent all those suffering from hereditary disease from having children by persuading them to use contraception or have themselves sterilized voluntarily. ${ }^{33} \mathrm{In}$ his book on the sexual question, Forel wrote: "It would be an immense progress if castration and Fallopian tube ligation performed with the consent of the criminal or patient were officially recognized in the civil legislation."

Such rather blunt ideas might have been in the mind of the politicians of the Canton de Vaud, who voted in 1928 the first European law on the sterilization of "psychically abnormal" individuals. Recently, some Swiss intellectuals have argued that the famous Vaudoise law of 1928 inspired the Nazi rulers in the formulation of their own sterilization law of 1934 and they have pointed to Forel and Bleuler as psychiatrists whose ideas led to the ferocious racial hygiene campaign that went on in Germany during World War II. ${ }^{34-36}$ The attacks on Forel became particularly vehement in 1997 and they may have played a role in the disappearance of Forel's effigy on one of the world's largest banknote (1000 Swiss franks, see Figure 5, lower panel) shortly thereafter. ${ }^{32}$ This harsh attitude towards Forel's views on sexuality is surprising and does not stand up to closer scrutiny. ${ }^{33}$ Detailed studies by Swiss specialists on the question of psychiatry and sexual violence have revealed that the Vaudoise law of 1928 was applied in a very limited and well-informed manner and thus cannot be considered as a truly eugenic measure. ${ }^{37,38}$ The eugenics practiced in the Canton de Vaud at the dawn of the 20th century was nothing more than a toile de fond that served to justify various social hygiene measures that could not be accounted for otherwise. ${ }^{38}$ Furthermore, the fact that Forel's statements on race, the death penalty, homosexuality, sexual equality, contraception, abortion, and sterilization were considered unacceptable by the Nazi officials, who finally banned his book on the sexual question, argues strongly against the notion that Forel's ideas may have influenced the Nazi racial policy. Obviously, Forel shared many errors with his contemporaries, but he was too honest, conscientious, and selfless to become guilty of the slightest inhumane act. ${ }^{33}$ His incursion into the delicate field of sexology, which led him to be considered as one of the founders of modern sexology by some ${ }^{33}$ and the ideologue of Enrich Himmler (1900-1945) by others, ${ }^{36}$ has unfortunately overshadowed his remarkable contribution to neurology and entomology. Forel's major input to these two fields of human knowledge deserves to be highlighted; it does not belong to the various issues that are at stake in the current questioning about national identity in Switzerland.

\section{ACKNOWLEDGEMENT}

The author thanks Professor Theodore L. Sourkes of McGill University for his critical reading of the manuscript and Martin Parent of Laval University for his precious help with the illustrations.

\section{REFERENCES}

1. Meynert T. Der Bau der Grosshirnrinde und seine örtlichen Verschiedenheiten, nebst einem pathologisch-anatomischen Corollarium. Leipzig: Engelmann, 1868.

2. Forel A. Beiträge zur Kenntnis des thalamus opticus und der ihn umgebenden Gebilde bei den Säugetieren. Sitzber Akad Wiss Wien 1872; 66 (Part 3): 25-58.

3. Forel A. Rückblick auf mein Leben. Zürich: Europa-Verlag, 1935.

4. von Gudden B. Über ein neues Microtom. Arch Psychiat Nervenkr 1875; 5: 229-234.

5. Forel A. Untersuchungen über die Haubenregion und ihre oberen Verknüpfungen im Gehirne des Menschen und einiger Saügethiere, mit Beiträgen $\mathrm{zu}$ den Methoden der Gehirnuntersuchung. Arch Psychiat Nervenkr 1877; 7: 393-495.

6. Luys JB. Recherches sur le système cérébro-spinal, sa structure, ses fonctions et ses maladies. Paris: Baillière, 1865.

7. Parent A. Jules Bernard Luys and the subthalamic nucleus. Mov Disord 2002; 17: 181-185.

8. Parent A, Parent M, Leroux-Hugon V. Jules Bernard Luys: A singular figure of 19th century neurology. Can J Neurol Sci 2002; 29: $282-288$

9. Forel A. Les fourmis de la Suisse: systématique, notices anatomiques et physiologiques, architecture, distribution géographique, nouvelles expériences et observations de mœurs. Zürich: Zurcher \& Furrer, 1874.

10. Forel A. Briefe correspondance: 1864-1927. Bern: Hans Huber, 1968.

11. Fritsch GT, Hitzig E. Über die elektrische Erregbarkeit des Grosshirns. Archiv für Anat Physiol Wiss Med 1870: 300-332.

12. Forel A. Der Hypnotismus; seine psycho-physiologische, medicinische, strafrechtliche Bedeutung. Stuttgart: Enke, 1895.

13. Mazzarello P. The hidden structure: a scientific biography of Camillo Golgi (translated by H.A. Buchtel and A. Baldini). Oxford: Oxford University Press, 1999.

14. Forel A. Einige hirnanatomische Betrachtungen und Ergebnisse. Arch Psychiat Nervenkr 1887; 18: 162-198.

15. Shepherd GM. Foundation of the neuron doctrine. New York: Oxford University Press, 1991.

16. Jacobson M. Foundations of neuroscience. New York: Kluver Academic/Plenum Publishers, 1993.

17. Clarke E, O'Malley CD. The human brain and spinal cord. A historical study by writing from antiquity to the twentieth century. Berkeley: University of California Press, 1968.

18. His W. Zur Geschichte des menschlichen Rückenmarkes und der Nervenwurzeln. Säch Akad Wiss Leipzig 1886; 13: 147-209, 477-513.

19. Ramón y Cajal S. Estrutura de los centros nervioso de los aves. Rev Trimes Histol Norm Pathol 1888; 1: 305-315.

20. von Kölliker AR. Handbuch der Gewebelehre des Menschen für Aerzte und Studirende. Leipzig: Engelmann, 1852.

21. von Waldeyer W. Über einige neuere Forschungen im Gebiete der Anatomie des Centralnervensystems. Deutsche med Wschr 1891; 
17: 1213-1218, 1244-1246, 1267-1269, 1287-1289, 1331-1332, $1352-1356$.

22. Bleuler E. Dementia praecox oder Gruppe des Schizophrenien. In: Aschaffenburg G, (Ed). Handbuch der Psychiatrie. Spezieller Teil. 4. Abteilung, 1. Häfte. Leipzig \& Wien: Deuticke, 1911.

23. Forel A. Die sexuelle Frage. Eine naturwissenschaftliche, hygienische und soziologische Studie. Munchen: Reinhardt, 1905.

24. Forel A. Leben und Tod. Ein Vortrag. Munchen: Reinhardt, 1908.

25. Clark JG, (ed). Clark University 1889-1899 Decennial Celebration. Worcester: Clark University Press, 1899.

26. Ramón y Cajal S. Las sensaciones de las hormigas. Real Sociedad Española de Historia Natural. 1921; Tomo del 50. ${ }^{\circ}$ aniv.: 555572.

27. Forel A. Le monde social des fourmis du globe comparé à celui de l'homme. Genève: Kündig (5 vol.), 1921-1923.

28. Tissot SA. Advice to people in general, with respect to their health (translated by J. Kirkpatrick). London: Becket \& de Hondt, 1768.

29. Tissot SA. Collection des ouvrages de médecine de M. Tissot. Paris, 1771.
30. Tissot SA. Traité des nerfs et de leurs maladies. Avignon: Chambeau, 1800.

31. Lavater JC. Von der Physiognomik. Leipzig: Weissmanns, Erben \& Reich, 1772

32. Forel A. L'âme et le système nerveux. Hygiène et pathologie. Paris: Steinheil, 1906.

33. Haeberle EJ. Auguste Forel - Der erste Schweizerische Sexologe. Neue Zürcher Zeitung, February 17, 1986.

34. Comment B. Les fourmis de la gare de Berne. Genève: Zoé, 1996.

35. Jost HU. Politik und Wirtschaft im Krieg. Die Schweiz. Zürich: Chronos, 1998.

36. Wottreng W. Hirnriss. Wie die Irrenärtze Auguste Forel und Eugen Bleuler das Menschengeschlecht retten wolten. Zürich: Weltwoche-ABC, 1999.

37. Jeanmonod G, Heller G, Gasser J. Déficience mentale et sexualité. La stérilisation légale dans le canton de Vaud entre 1928 et 1985. Médecine et Hygiène 2000; 57: 2050-2054.

38. Gasser J, Heller G, Jeanmonod G. Autour de la stérilisation non volontaire en Suisse Romande durant le $20^{\mathrm{e}}$ siècle. Revue médicale de la Suisse Romande 2002; 122: 47-53. 